\title{
Maspin expression in gastrointestinal stromal tumors
}

Saduman Balaban Adim ${ }^{1 *}$, Gulaydan Filiz' ${ }^{1}$ Ozkan Kanat ${ }^{2}$, Omer Yerci ${ }^{1}$, Halil Ozguc $^{3}$, Berna Aytac ${ }^{1}$

\begin{abstract}
Background: To investigate the role of maspin expression in the progression of gastrointestinal stromal tumors, and its value as a prognostic indicator.

Methods: In the study 54 patients with GIST diagnosis were included in Uludag University of Faculty of Medicine, Department of Pathology between 1997-2007. The expression of maspin in 54 cases of gastrointestinal stromal tumor was detected by immunohistochemistry and compared with the clinicopathologic tumor parameters.

Results: The positive expression rates for maspin in the GISTs were 66,6\% (36 of 54 cases). Maspin overexpression was detected in 9 of 29 high risk tumors (31\%) and was significantly higher in very low/low (78.6\%) and intermediate-risk tumors (63.6\%) than high-risk tumors.

Conclusions: Maspin expression might be an important factor in tumor progression and patient prognosis in GIST. In the future, larger series may be studied to examine the prognostic significance of maspin in GISTs and, of course, maspin expression may be studied in different mesenchymal tumors.
\end{abstract}

\section{Background}

Gastrointestinal stromal tumors (GISTs) are the most common mesenchymal tumors of the gastrointestinal tract. These tumors may occur in any region but are most commonly reported in the stomach and the small intestine [1-7]. GISTs originate from the neoplastic transformation of the intestinal pacemaker cell, the interstitial cell of Cajal. Cajal cells are neuron-derived cells that migrate from the neural crest to the intestine, and the GISTs stemming from these are different from classical mesenchymal tumors such as leiomyoma [8].

GISTs have a wide spectrum of biological behavior ranging from benign to malignant [1,2]. Despite clearly defined conventional histological criteria such as tumor size and mitotic index, the prediction of the clinical course of these tumors is often difficult [6]. Therefore it is important to investigate alternative markers that allow better prognostic assessment.

Maspin (mammary serine protease inhibitor) is a member of the serpin superfamily of protease inhibitors, which also acts as a tumor suppressor [9]. The mechanism of its tumor suppressor effect is still not understood

\footnotetext{
* Correspondence: sadumanbalaban@hotmail.com

'Department of Surgical Pathology, Uludag University, Faculty of Medicine, Gorukle, Bursa, 16059, Turkey
}

clearly. It is suggested that maspin prevents invasion and metastases of tumors by inhibiting tumor-induced angiogenesis and tumor cell motility [10-13]. In addition, it is reported to induce apoptosis of neoplastic cells [14]. Maspin expression has been demonstrated in multiple tissues including breasts, prostate, placenta, small intestine, colon, uterus, kidney, thymus, and testis [15-18]. On the other hand, it is expressed at different levels in many solid tumors. In breast, colon, stomach, thyroid, bladder, and prostate cancers, in lung and oral cavity squamous cell carcinoma, and in certain renal neoplasms, maspin expression seems to predict a better prognosis [13,19-22]. In contrast, some studies have shown that maspin overexpression is correlated with a poor prognosis in pancreatic and ovarian cancers and in lung adenocarcinoma [23-25].

To the best of our knowledge, no study yet exists about the presence of maspin expression in mesenchymal and neural tumors. On the other hand, existing studies report that maspin expression does not occur in mesenchymal tissue other than corneal stromal cells. Similarly, GISTs have not yet been studied in relation to maspin expression and prognostic meaning. The aim of this study was an immunohistochemical evaluation of maspin expression in these tumors. 


\section{Methods}

Between 1997 and 2007, fifty-four patients with GIST who underwent surgical resection in Uludag University of Faculty of Medicine were selected for this study. Seven of the patients had distant metastasis at the time of presentation. Ethical approval was obtained for the study. All specimens of the 54 patients showed positive CD117 and/or CD34 immunostaining. According to the classification system proposed by Fletcher et al. (Table 1), 29 (53.7\%) patients belonged to the high-risk group. Forty-two $(77.8 \%)$ patients had tumors $\geq 5 \mathrm{~cm}$, and $32(59.2 \%)$ had mitotic counts $\geq 5 / 50$ high power fields (HPF).

\section{Immunohistochemistry}

The cellular expression of maspin was assessed by immunohistochemistry (IHC) using specific antibody on routinely processed blocks of formalin-fixed and paraffinembedded surgical specimens of the tumors. The $4 \mu \mathrm{m}$ sections of tumor tissues were mounted on poly-L-lysine coated slides. The sections were deparaffinized in xylene (25 min) and rehydrated through serial baths of alcohol to water. Antigen retrieval was applied with pressure cooking using $500 \mathrm{ml} 1 \mathrm{mM}$ diluated EDTA-Saline buffer ( $\mathrm{pH}=8$ ). After using $\mathrm{H}_{2} \mathrm{O}_{2}$ treatment for 15 minutes to remove endogenous peroxidase activity, nonspecific blockage with ultrablock nonspecific blocking agent (Labvision Co.) was performed on all sections for 10 minutes. Then the sections were incubated with primary antibody maspin AB-1 (Clone EAW24, Mouse monoclonal antibody, Thermo Scientific, USA) 1/20 in dilution at room temperature for 30 minutes. The antibody-treated slides were rinsed in phosphate-buffered saline solution and incubated with a biotinylated secondary antibody (Ultravision-Labcision Co., Fremont, CA, U.S.A.). The slides were washed in phosphate-buffered saline and then incubated with an avidin-biotin-preoxidase complex (Ultrastreptavidin/HRP, Labvision Co.) for 30 minutes. As a chromogen, 3-3'-diamino-benzene tetrahydrochloride was used with hydrogen peroxide. The slides were finally counterstained with hematoxylin. Prostate tissue was used as positive control.

Table 1 Risk of Aggressive Behavior in GISTs (Fletcher et al, 2002)

\begin{tabular}{lll}
\hline & Size (largest dimension) & Mitotic Count \\
\hline Very low risk & $<2 \mathrm{~cm}$ & $<5 / 50 \mathrm{HPF}$ \\
\hline Low risk & $2-5 \mathrm{~cm}$ & $<5 / 50 \mathrm{HPF}$ \\
\hline Intermediate risk & $<5 \mathrm{~cm}$ & $6-10 / 50 \mathrm{HPF}$ \\
\cline { 2 - 3 } & $5-10 \mathrm{~cm}$ & $<5 / 50 \mathrm{HPF}$ \\
\hline High risk & $>5 \mathrm{~cm}$ & $>5 / 50 \mathrm{HPF}$ \\
\cline { 2 - 3 } & $>10 \mathrm{~cm}$ & any mitotic rate \\
\hline
\end{tabular}

\section{Evaluation of staining for Maspin}

Maspin expression was determined semiquantitatively by the percentage of stained cells, the staining intensity, and subcellular localization [23].

- The percentage of positive cells was rated as follows: 0 points, no positive cells; 1 point, $0-5 \%$; 2 points, 6-50\%; 3 points, $50-100 \%$ positive cells.

- Staining intensity was rated as follows: 1 point, weak intensity; 2 points, moderate intensity; 3 points, strong intensity.

- Points for intensity and the percentage of positive cells were added to obtain an overall maspin score (OMS) [0-3]. Lesions were categorized into four groups:

1) Negative (OMS =0): < 5\% stained cells regardless of intensity

2) Weak expression (OMS = 1): 3 points

3) Moderate expression (OMS = 2): 4-5 points

4) Strong expression (OMS = 3): 6 points

- OMS 2 \& 3 was considered as overexpression.

\section{Statistical analysis}

All statistical analyses were performed using SPSS (Statistical Package for the Social Sciences, Chicago, IL) for Windows version 15.0. Survival time was calculated starting from the date of initial surgery.

The Chi-square and Fisher's exact tests were used to evaluate correlations between variables. $P<0.05$ was considered statistically significant. Survival times were calculated by using the Kaplan-Meier method and compared with the log-rank test.

\section{Results}

Of the 54 patients included in this study, 35 (64.8\%) were male and $19(35.2 \%)$ were female (Table 2). The mean age was 55.8 years (range 17-75 years). Tumor localizations were as follows: 23 stomach (42.6\%), 18 small intestine (33.3\%), 10 mesentery (18.5\%), 2 large intestine (3.7\%), and 1 esophagus (1.85\%). The sizes of tumor varied between 2 and $29 \mathrm{~cm}$ (median $7 \mathrm{~cm}$ ). Mitotic count varied between 0 and 61 mitoses per 50 HPF (median 11).

Among 54 tumors, 18 were OMS $=0 ; 9$ were OMS = $1 ; 8$ were OMS $=2$; and 19 were OMS $=3$ (Figure 1 ). When risk groups were compared, a meaningful difference was observed between low- and high-risk groups, as well as between intermediate- and high-risk groups (chi square test: $\mathrm{P}=0,009 ; \mathrm{P}=0,029$ )(Table 3 ).

Follow-up period ranged between 2 and 115 months (median: 40.77 months). At the end of the follow up, 37 patients were alive without any evidence of the disease, while 16 had died of the disease and one patient with 
Table 2 Clinicopathological characteristics of GIST patients

\begin{tabular}{ll}
\hline Variable & $\mathbf{n}$ \\
\hline Age, yr & $55,83 \pm 12,93$ \\
\hline Gender (Male/Female) & $35 / 19$ \\
\hline Tumor size & 12 \\
\hline $5 \mathrm{~cm}<$ & 42 \\
\hline $5 \mathrm{~cm} \geq$ & 22 \\
\hline Mitosis (50 HPP) & 32 \\
\hline $5<$ & 23 \\
\hline $5 \geq$ & 18 \\
\hline Localization & 2 \\
\hline Stomach & 10 \\
\hline Small intestine & 1 \\
\hline Large intestine & 14 \\
\hline Meso-peritoneum & 11 \\
\hline Eusophagus & 29 \\
\hline Risk Group & \\
\hline Low (very low and low) & \\
\hline Intermediate & \\
\hline High & \\
\hline
\end{tabular}

benign GIST had died of acute pancreatitis. At the time of diagnosis, metastasis was seen in 7 of the high risk tumor patients, and not in others. Overexpression was observed in only 1 of these 7 patients. The maspin $+/$ ratio in the 47 non metastatic patients was $21 / 26$ ( $\mathrm{p}=$ 0,050).

Overall mean survival length was 54.67 months. It was 56.19 months in maspin (+) patients and 53.29 months
Table 3 Correlation of clinicopathological variables with maspin overexpression.

\begin{tabular}{|c|c|c|c|c|}
\hline \multirow[b]{2}{*}{ Variable } & \multicolumn{4}{|c|}{ Maspin overexpression } \\
\hline & $54(\%)$ & $\begin{array}{l}\text { No }(n=27) \\
(\% 50)\end{array}$ & $\begin{array}{l}\text { Yes }(n=27) \\
(\% 50)\end{array}$ & $P$ value \\
\hline Size & & & & 0,769 \\
\hline $5 \mathrm{~cm}<$ & 12 & 6 & 6 & \\
\hline $5 \mathrm{~cm} \geq$ & 42 & 21 & 21 & \\
\hline Mitotic count (50 BB) & & & & 0,525 \\
\hline $5<$ & 22 & 7 & 15 & \\
\hline $5 \geq$ & 32 & 20 & 12 & \\
\hline \multicolumn{5}{|c|}{ Risk Group (compared with high risk group and others) } \\
\hline Very low and low & 14 & 3 & 11 & 0,009 \\
\hline Intermediate & 11 & 4 & 7 & 0,029 \\
\hline High & 29 & 20 & 9 & \\
\hline
\end{tabular}

in maspin (-) patients. There was no difference in survival rates between the groups $(\mathrm{p}>0.05)$.

\section{Discussion}

GISTs are a rare special mesenchymal tumor group, making up less than $1 \%$ of primary tumors of the gastrointestinal system [1]. Their biological behavior is hard to predict [2]. Many macroscopic and microscopic parametres have been suggested to identify the prognosis, including tumor localization and diameter, invasion of peripheral tissue, growth pattern, mucosal invasion, predominant tumor cell type, cellularity, nuclear pleomorphism, mitotic count, Ki67 proliferative activity index, p53 gene mutation, histological grade, DNA analysis, margins of surgical operation, necrosis and immunophenotyping [1-7]. Even though efforts continue for
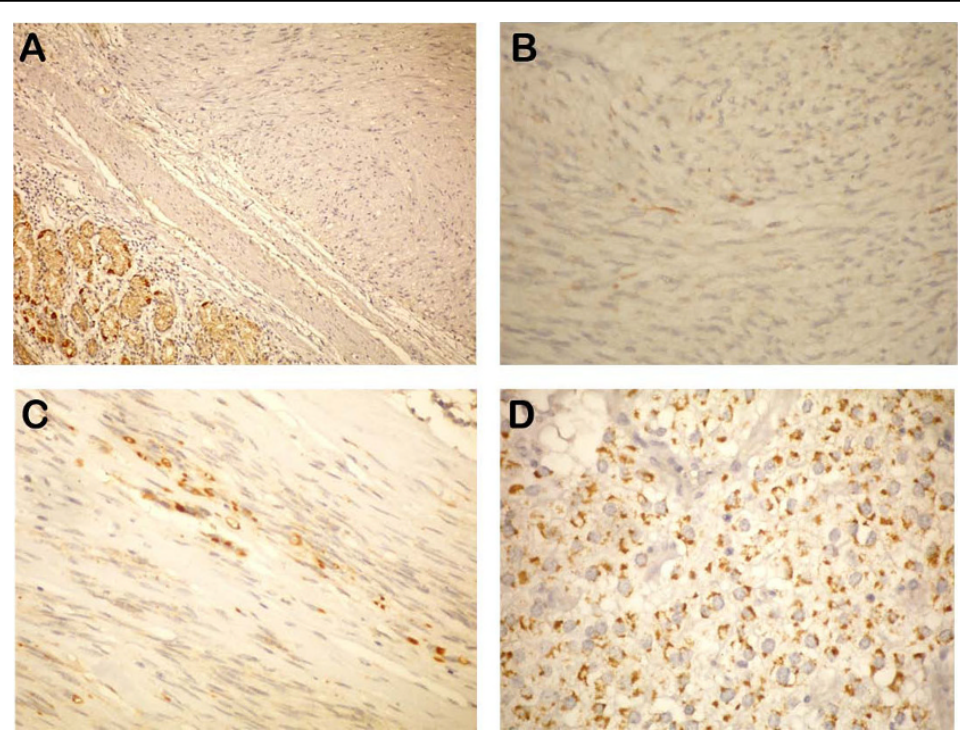

Figure 1 A) OMS score (-), B) OMS score $(1+)$, C) OMS score (2+), D) OMS score (3+) staining paterns in GIST's. 
the identification of new parameters, tumor diameter and mitotic index (mitotic count/50 BBA) currently remain the most important morphological criteria for the prediction of tumor behavior $[2,6]$.

Proteinases and proteinase inhibitors are known to play an important role in tumor invasion and metastasis. Proteinases degrade the extracellular matrix, while their inhibitors antagonize this process. Two classes of proteinases have been extensively studied: serine proteinases and their inhibitors, and metalloproteinases and their inhibitors [26]. Maspin (mammary serine protease inhibitor) is structurally a member of the serpine (serine protease inhibitors) superfamily [27]. Studies have revealed that maspin is largely an intracellular protein, which is soluble in the cytoplasm and associated with secretory vesicles. It is located at the cell membrane interface with extracellular matrix and does not act as a classical inhibitory serpine with antiprotease activity against trypsin-like proteases [28].

Maspin expression has been shown in the literature in epithelial and myoepithelial cells in certain tissues, most notably in the breasts and prostate, as well as neoplasms stemming from these tissues [15-18]. Many articles have described a negative association between maspin expression and carcinoma progression in several malignancies, including those of the breast, prostate, colon, bladder, thyroid and stomach cancers, lung and oral cavity squamous cell carcinoma, and some renal neoplasms [13,19-22]. Chen and Yates reported that maspin has suppressive effects on invasion and metastasis of carcinoma [29]. However, enhanced maspin expression may have an impact on different steps in the progression to pancreatic and ovarian carcinoma [23-25]. In addition, different results were also obtained for the same cancer type in different studies [21,30]. These contradictory results might result from specific regulation in different organs or the different genetic backgrounds of the populations studied, although definite evidence for a paradoxical mechanism remains elusive.

While existing studies report that maspin expression does not occur in mesenchymal and neural crest cells other than corneal stromal cells, the literature does not include any studies about maspin expression in mesenchymal and neural tumors, except gliomas $[18,31,32]$. Similarly, no study exists to show the relationship between maspin expression and prognosis in GIST patients.

Although the molecular and biological mechanisms of the function(s) of maspin remain largely unknown at present, there is evidence that maspin interacts with the p53 tumor suppressor pathway and may function as inhibitor to cell motility, invasion, metastasis and angiogenesis in vitro and in vivo [23]. Also, maspin appears to be regulated by wild-type p53. Zou et al. reported that there was robust induction of maspin in prostate and breast cancer cells after wild-type p53 expression [33]. p53 was found to activate maspin promoter by binding directly to the p53 consensus binding site present in the maspin promoter. Some GISTs are known to harbor p53 gene mutations $[34,35]$.

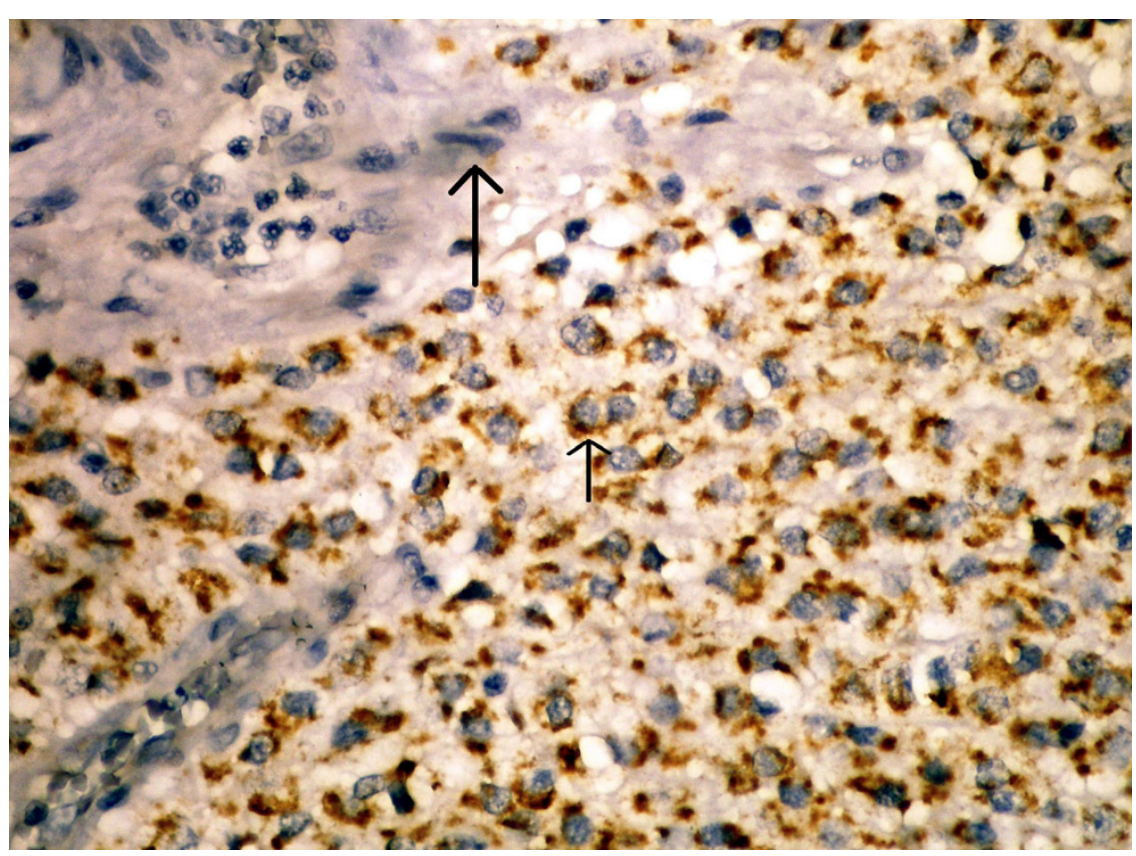

Figure 2 Positive staining in tumor cell's cytoplasm for maspin (short arrow) but not stain in endothelial cells (long arrow). $(\times 200)$ 
In this study, we primarily studied the existence of maspin expression in GIST cases. We immunohistochemically observed maspin staining in $36(66,6 \%)$ out of our 54 cases. In half of these patients, we obtained $5 \%$ or more positive cytoplasmic staining with maspin, whereas in $16,6 \%$ of them we obtained less than $5 \%$ staining. In the blocks we studied, we detected cytoplasmic staining with maspin in the mucosa epithelium of normal tissues belonging to the gastrointestinal tract neighboring the tumor, but no staining in mesenchymal cells (smooth muscle cells, endothelial cells, etc.). No staining occurred in the endothelial cells of tumor tissue either (Figure 2). Following these, we analyzed the prognostic significance of maspin expression in GISTs.

In our study, maspin expression was significantly correlated with the risk grade of GISTs. Maspin overexpression was detected in 9 of 29 high risk tumors (31\%) and was significantly higher in very low/low- $(78.6 \%)$ and intermediate-risk tumors (63.6\%) than high-risk tumors.

As low-risk patients have higher maspin overexpression and high-risk patients have less, it may be claimed that maspin overexpression is a favorable prognosis marker.

\section{Conclusions}

Our preliminary results suggest that expression level of maspin may be considered a predictor of prognosis in GISTs. Future studies with larger patient numbers will be essential to confirm the prognostic significance of maspin in patients with GIST and other mesenchymal tumors.

\footnotetext{
Author details

'Department of Surgical Pathology, Uludag University, Faculty of Medicine, Gorukle, Bursa, 16059, Turkey. '2Department of Medical Oncology, Uludag University, Faculty of Medicine, Gorukle, Bursa, 16059, Turkey. ${ }^{3}$ Department of Surgery, Uludag University, Faculty of Medicine, Gorukle, Bursa, 16059, Turkey.
}

\section{Authors' contributions}

SBA designed the study, researched the literature, and drafted the manuscript. SBA, GF, OY, and BA contributed to the histopathological analyses. $\mathrm{OK}$ and $\mathrm{HO}$ participiated in the study design and coordination, and helped to collect data.

\section{Competing interests}

The authors declare that they have no competing interests.

Received: 18 December 2009 Accepted: 26 March 2010 Published: 26 March 2010

\section{References}

1. Stamatakos M, Douzinas E, Stefanaki C, Safioleas P, Polyzou E, Levidou G, Safioleas M: Gastrointestinal stromal tumor. World J Surg Oncol 2009, 7:61.

2. Duffaud F, Blay JY: Gastrointestinal stromal tumors: biology and treatment. Oncology 2003, 65:187-197.

3. Deitos AP: The reapraisal of gastrointestinal stromal tumors: from stout to the KIT revolution. Virchows Arch 2003, 442:421-428.

4. Connolly EM, Gaffney E, Reynolds JV: Gastrointestinal stromal tumors. British Journal of Surgery 2003, 90:1178-1186.
5. Miettinen M, Lasota J: Gastrointestinal stromal tumors-definition, clinical, histological, immunohistochemical, and molecular genetic features and differential diagnosis. Virchows Arc 2001, 438:1-12.

6. Fletcher CDM, Berman JJ, Corless C, Gorstein F, Lasota J, Longley BJ, Miettinen M, O'Leary TJ, Remotti H, Rubin BP, Shmookler B, Sobin LH, Weiss SW: Diagnosis of gastrointestinal stromal tumors: a consensus approach. Human Pathology 2002, 33:459-465.

7. Date RS, Stylianides NA, Pursnani KG, Ward JB, Mughal MM: Management of gastrointestinal stromal tumours in the Imatinib era: a surgeon's perspective. World J Surg Oncol 2008, 18(6):77.

8. Sircar K, Hewlett BR, Huizinga JD, Chorneyko K, Berezin I, Riddell RH: Interstitial cells of cajal as precursors of gastrointestinal stromal tumors. Am J Surg Pathol 1999, 23:377-389.

9. Zou Z, Anisowicz A, Hendrix MJ, Thor A, Neveu M, Sheng S, Rafidi K, Seftor E, Sager R: Maspin, a serpin with tumor-suppressing activity in human mammary epithelial cells. Science 1994, 263:526-529.

10. Bailey CM, Khalkhali-Ellis Z, Seftor EA, Hendrix MJ: Biological functions of maspin. J Cell Physiol 2006, 209:617-624.

11. Schaefer JS, Zhang M: Role of maspin in tumor metastasis and angiogenesis. Curr Mol Med 2003, 3:653-658.

12. Sheng S, Carey J, Seftor EA, Dias L, Hendrix MJ, Sager R: Maspin acts at the cell membrane to inhibit invasion and motility of mammary and prostatic cancer cells. Proc Natl Acad Sci USA 1996, 93:11669-11674

13. Zhang $M$, Volpert $O$, Shi $Y H$, Bouck $N$ : Maspin is an angiogenesis inhibitor. Nat Med 2000, 6:196-199.

14. Jiang N, Meng Y, Zhang S, Mensah-Osman E, Sheng S: Maspin sensitizes breast carcinoma cells to induced apoptosis. Oncogene 2002, 21:4089-4098.

15. Pemberton PA, Tipton AR, Pavloff N, Smith J, Ericson JR, Mouchabeck ZM, Kiefer MC: Maspin is an intracellular serpin that partitions into secretory vesicles and present at the cell surface. J Histochem Cytochem 1997, 45:1697-1706.

16. Zou Z, Anisowicz A, Hendrix MJ, Thor A, Neveu M, Sheng S, Rafidi K, Seftor E, Sager R: Maspin a serpin with tumor-suppressing activity in human mammary epithelial cells. Science 1994, 263:526-529.

17. De Lima Navarro R, Trierveiler Martins M, Cavalcanti de Araujo V: Maspin expression in normal and neoplastic salivary gland. J Oral Pathol Med 2004, 33:435-440.

18. Reis-Filho JS, Torio B, Albergaria A, Schmitt FC: Maspin expression in normal skin and usual cutaneous carcinomas. Virchows Arch 2002, 441:551-558.

19. Nakagawa M, Katakura H, Adachi M, Takenaka K, Yanagihara K, Otake Y, Wada H, Tanaka F: Maspin expression and its clinical significance in nonsmall cell lung cancer. Ann Surg Oncol 2006, 13:1517-1523.

20. Boltze C: Loss of maspin is a helpful prognosticator in colorectal cancer: a tissue microarray analysis. Pathol Res Pract 2005, 200:783-790.

21. Ito R, Nakayama H, Yoshida K, Oda N, Yasui W: Loss of maspin expression is associated with development and progression of gastric carcinoma with p53 abnormality. Oncol Rep 2004, 12:985-990.

22. Friedrich MG, Toma MI, Petri S, Cheng JC, Hammerer P, Erbersdobler A, Huland $\mathrm{H}$ : Expression of maspin in non-muscle invasive bladder carcinoma: correlation with tumor angiogenesis and prognosis. Eur Urol 2004, 45:737-743.

23. Sood AK, Fletcher MS, Gruman LM, Coffin JE, Jabbari S, Khalkhali-Ellis Z, Arbour N, Seftor EA, Hendrix MJC: The paradoxical expression of maspin in ovarian carcinoma. Clin Cancer Res 2002, 8:2924-2932.

24. Maass N, Hojo T, Ueding M, Luttges J, Kloppel G, Jonat W, Nagasaki K: Expression of the tumor suppressor gene Maspin in human pancreatic cancers. Clin Cancer Res 2001, 7:812-817.

25. Logsdon CD, Simeone DM, Binkley C, Arumugam T, Greenson JK, Giordano TJ, Misek DE, Hanash S: Molecular profiling of pancreatic adenocarcinoma and chronic pancreatitis identifies multiple genes differentially regulated in pancreatic cancer. Cancer Res 2003, 63:2649-2657.

26. DeClerck YA, Mercurio AM, Stack MS, Chapman HA, Zutter MM, Muschel RJ, Raz A, Matrisian LM, Sloane BF, Noel A, Hendrix MJ, Coussens L, Padarathsingh M: Proteases, extracellular matrix and cancer. American Journal of Pathology 2004, 164:1131-1139.

27. Shi HY, Liang R, Templeton N, Zhang M: Characterization and systemic treatment of maspin in a breast metastasis model. Molecular Therapy 2002, 5:755-761. 
28. Maass N, Biallek M, Rösel F, Schem C, Ohike N, Zhang M, Jonat W, Nagasaki K: Hypermethylation and histone deacetylation lead to silencing of the maspin gene in human breast cancer. Biochem Biophys Res Commun 2002, 297:125-128.

29. El Chen, JR Yates: Maspin and tumor metastasis. IUBMB Life 2006, 58:25-29.

30. Yu M, Zheng H, Tsuneyama K, Takahashi H, Nomoto K, Xu H, Takano Y: Paradoxical expression of maspin in gastric carcinomas: correlation with carcinogenesis and progression. Hum Pathol 2007, 38:1248-55.

31. Ngamkitidechakul C, Burke JM, O'Brien WJ, Twining SS: Maspin: synthesis by human cornea and regulation of in vitro stromal cell adhesion to extracellular matrix. Invest Ophthalmol Vis Sci 2001, 42:3135-3141.

32. Wang DL, Wang YF, Shi GS, Huang H: Correlation of hTERT expression to maspin and bFGF expression and their significance inglioma. Ai Zheng 2007, 26:601-606.

33. Zou Z, Gao C, Nagaich AK, Connell T, Saito S, Moul JW, Seth P, Appella E, Srivastava S: P53 regulates the expression of the tumor suppressor gene maspin. J Biol Chem 2000, 275:6051-6054.

34. Yalcinkaya U, Yerci O, Koc EU: Significance of p53 expression in gastrointestinal stromal tumors. Hepatogastroenterology 2007, 54:140-143.

35. Pauser U, Schmedt Auf der Günne N, Klöppel G, Merz H, Feller AC: P53 expression is significantly correlated with high risk of malignancy and epithelioid differentiation in GISTs. An immunohistochemical study of 104 cases. BMC Cancer 2008, 8:204-210.

doi:10.1186/1477-7819-8-22

Cite this article as: Adim et al:: Maspin expression in gastrointestinal stromal tumors. World Journal of Surgical Oncology 2010 8:22.

\section{Submit your next manuscript to BioMed Central and take full advantage of:}

- Convenient online submission

- Thorough peer review

- No space constraints or color figure charges

- Immediate publication on acceptance

- Inclusion in PubMed, CAS, Scopus and Google Scholar

- Research which is freely available for redistribution

Submit your manuscript at www.biomedcentral.com/submit 